\title{
Influence of temperature and soil type on the histopathology of Meloidogyne incognita on snap beans'
}

\author{
Nydia E. Vicente, Alejandro Ayala and Nelia Acosta
}

\begin{abstract}
Three groups of seedlings of snap bean cultivars Contender and Conquest were planted in Cato clay, Fraternidad silty clay, and San Antón silt loam; inoculated with 10,000 eggs and second stage juveniles of Meloidogyne incognitaand placed in growth chambers at 15, 20 and $25^{\circ}$ $C$ for $\mathbf{4 5}$ days. Multinucleate giant cells with thick cell walls and dense cytoplasm surrounded by proilferation of small cells, breakdown of cell walls, and malformation of vascular bundles were observed. No giant cells were observed in bacterial nodules, even though several of them were invaded by nematodes. Cyfoplasmic content of the giant cells decreased as temperature increased. Nematode numbers within roots increased as the temperature increased. There was a tendency for the formation of oval or rectangular giant cells around the vascular bundles and round giant cells in the cortex. Giant cells with the largest number of nuclei were observed af $20^{\circ} \mathrm{C}$, and fewer at $25^{\circ} \mathrm{C}$. Giant cell was largest at 20 and $25^{\circ} \mathrm{C}$, especially in cv Contender. Necrosis or mechanic injury due to migration of juveniles was not observed. The nematodes appeared to develop best in Fraternidad soil.
\end{abstract}

\section{INTRODUCTION}

Snap beans, Phaseolus vulgaris L., are among the most popular fresh vegetables in Puerto Rico (16). Production during $1983-84$ was $86,364 \mathrm{~kg}$, whereas importations of canned string beans amounted to $2,387,273 \mathrm{~kg}$ (3). In the United States, phytoparasitic nematodes cause losses of 5\% of the total snap bean production (9). Meloidogyne incognita (Kofoid and White) Chitwood is one of the most important nematodes affecting this crop $(13,18)$.

It has been reported that the behavior of Meloidogyne species is affected by environmental factors such as temperature and soil texture $(14,17)$. Temperature is of particular importance and often affects the nematode action within the plant.

The histopathology of root-knot nematodes has been studied in several crops $(1,2,4,10)$, but research on nematode effects on snap bean cells has been limited (6). The objective of this study was to determine the influence of temperature and soil type on the histopathology of rootknot nematodes in beans.

'Manuscript submitted to Editorial Board January 14, 1986.

2Research Assistant and Nematologists, respectively, Department of Crop Protection, University of Puerto Rico, Mayaguez, Puerto Rico 00708. 

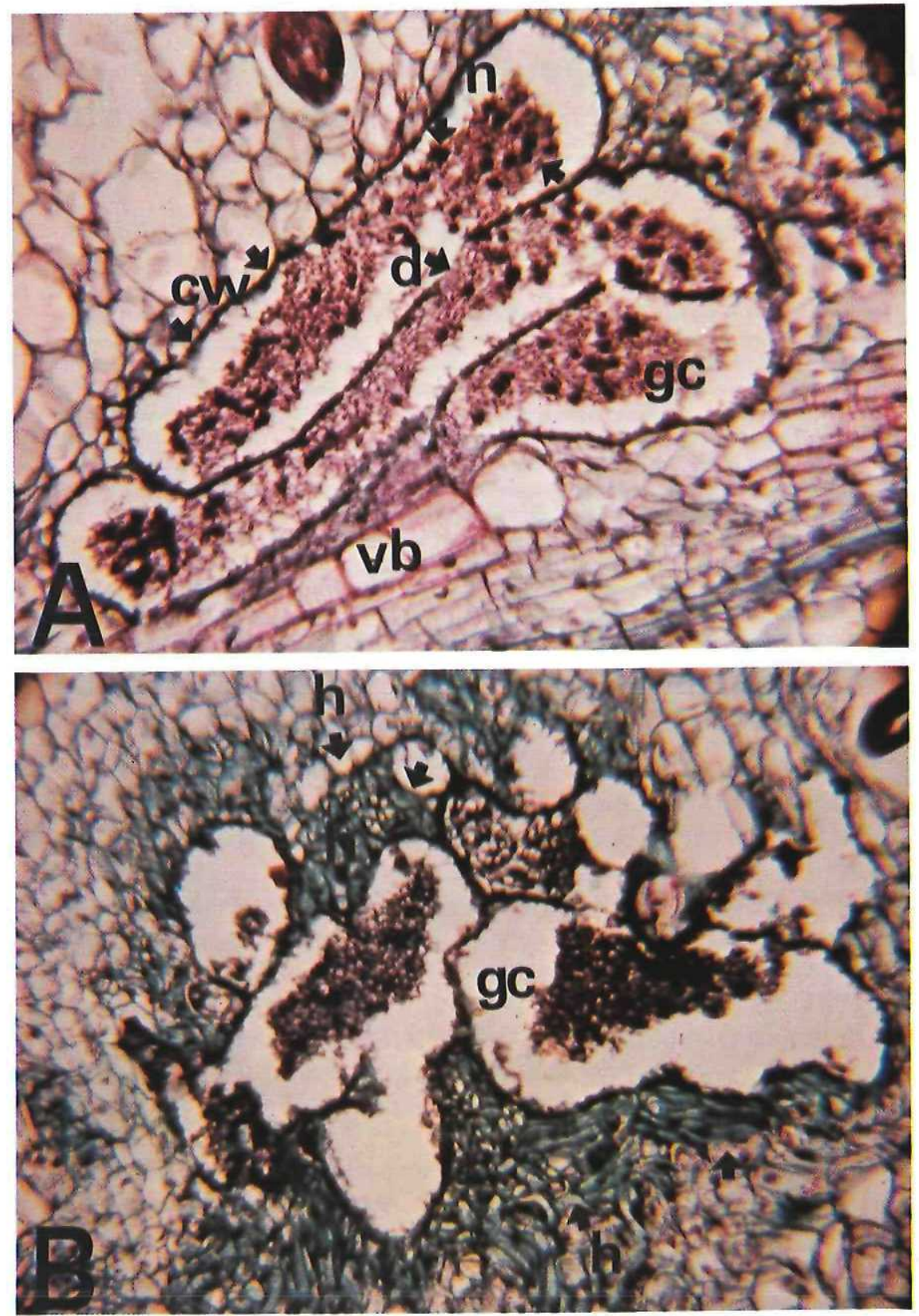

FIG. 1.-Histopathology of roots of snap bean, cv Conquest at $15^{\circ} \mathrm{C}, 45$ days after inoculation with $M$. incognita. A) Longitudinal section showing giant cells (gc) close to vascular bundles (vb), proliferation of nuclei (n), thick-cell walls (cw) and cell wall dissolution (d). B) Longitudinal section exhibiting hyperplasia (h) around giant cells (g) and the aggregation of cytoplasm particles. 

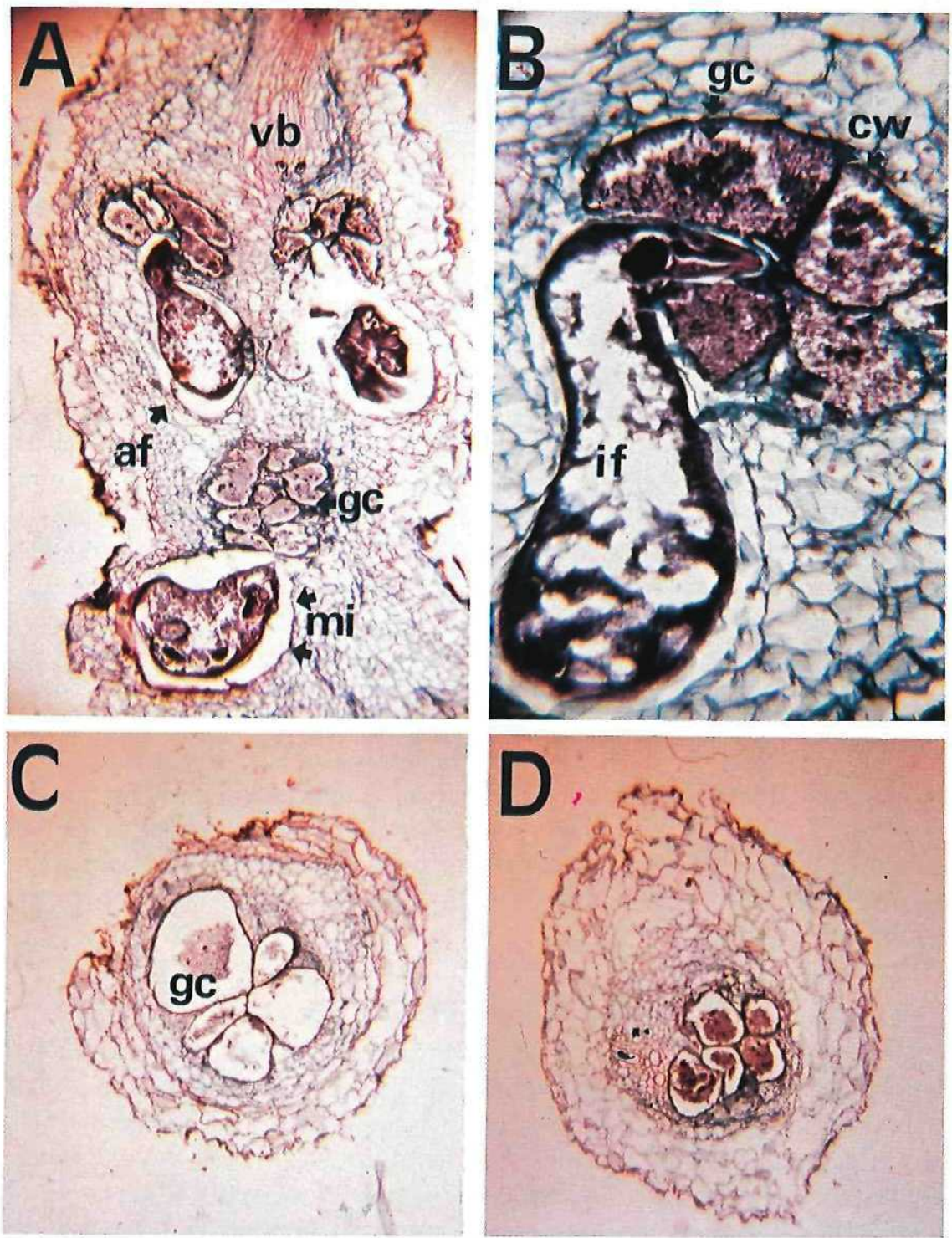

Fig. 2.-Histopathology of roots of snap bean, cvs Contender and Conquest at $15^{\circ} \mathrm{C}$, 45 days after inoculation with $M$. incognita. A, B) Longitudinal sections of cv Conquest (A) and Contender (B) revealing adult females (af) and immature females (if), dense cytoplasmic content, giant cells (gc), thick-cell walls (cw), mechanic injury (mi) due to female growth and malformation of vascular bundles (vb). C, D) Transverse sections exhibiting very large giant cells (gc) in cv Contender (C) and small ones in cv Conquest (D). 


\section{MATERIALS AND METHODS}

Experiments were conducted from January to August 1982, to compare the histological effects on snap bean cultivars Contender and Conquest attributable to $M$. incognita when the plants were grown in three different soil types: Coto clay ( $\mathrm{pH} 7.72$, organic matter, $3.5 \%$ ) from Isabela; Fraternidad silty clay ( $\mathrm{pH} 7.31$, organic matter, $3.12 \%$ ) from Lajas; and San Antón silt loam ( $\mathrm{pH} 7.89$, organic matter, $2.87 \%$ ) from Santa Isabel at three constant temperatures: 15,20 and $25^{\circ} \mathrm{C}$.

Pre-germinated bean seeds were planted in $10 \mathrm{~cm}$ plastic pots filled with soil previously sterilized with methyl bromide. Pots were maintained in the greenhouse for 7 days, then inoculated with 10,000 eggs and 2nd stage juveniles of $M$. incogrita per pot, extracted from infected tomato roots, Lycopersicon esculentum $\mathrm{cv}$ Rutgers. Inoculum was obtained by the Hussey and Barker method (7). Plants that served as control received tap water only. The plants were then transferred to growth chambers under constant temperature for 45 days. Five plants served as replication for each treatment and were distributed completely randomized in the growth chamber.

Forty-five days after inoculation, histological analyses of root sections were made to determine the effect of the nematode on the root tissue. Samples of infected root pieces were preserved in FAA (formalin acetoalcohol) according to Johansen's method (8). Roots were cut into 1-cm. pieces, dehydrated in tert-butyl alcohol and infiltrated in paraplast (melting point $56-57^{\circ} \mathrm{C}$ ). Root pieces were sectioned transversally and longitudinally to a thickness of $12 \mu$ with a rotary microtome. Sections were mounted on glass slides, stained with safranine $O$ and fast green, and examined microscopically.

\section{RESULTS AND DISCUSSION}

Snap bean plants grown at $15^{\circ} \mathrm{C}$ developed normal roots and foliage both in nematode inoculated and noninoculated plants. Inoculated plants exhibited small, almost undetectable nematode galls. Bacterial nodules were large on all plants. At $20^{\circ} \mathrm{C}$, plants grown in Coto clay exhibited small root systems and thin roots, especially in inoculated plants, Root development in noninoeulated plants appeared normal. Nematode galls and bacterial nodules were clearly observed in inoculated plants.

At $25^{\circ} \mathrm{C}$, all roots from inoculated plants showed numerous nematode galls and bacterial nodules. The latter were smaller at $25^{\circ} \mathrm{C}$ than at 15 and $20^{\circ} \mathrm{C}$. In general, root systems were smaller at 25 than at $20^{\circ} \mathrm{C}$. Plants grown in Coto clay showed relatively small root systems. On many occasions nematodes invaded the base of the stems.

Histological sections revealed the presence of many giant cells in all the inoculated plants at all temperature and all soil types. These cells 
were larger than normal cells, multinucleate and with dense cytoplasm and thick cell walls (figs. $1 \mathrm{~A}$ and $\mathrm{B}$ ). We observed hyperplastic zones and excessive proliferation of completely disorganized small cells surrounding the giant cells (fig. 1B). The presence of this type of giant cells confirms the susceptibility of both cultivars to $M$. incognita. Martinez's findings on dry bean (10) are similar to ours. According to Fassuliotis (6), giant cells in resistant cultivars are relatively small and are confined to the nematode head area. Plant tissues most frequently invaded by nematodes were the root cortex, pericycle and vascular bundles. These results are consistent with those of Martínez (10), Negrón (11) and Toro (15).

Nematodes were observed in bacterial nodules, but giant cell formation, or structural changes were not associated with them (fig. 3A). Similar results were obtained in soybean by Hussey and Barker (7).

Temperature was the determining factor in nematode development. At $15^{\circ} \mathrm{C}$, we observed few juveniles, sausage stage and immature females. No mature females (with egg masses) nor males were observed. At $20^{\circ} \mathrm{C}$, almost all developmental stages were observed in all soil types, but juveniles were found only in cv Contender grown in Coto and Fraternidad soils. Immature and mature females were present in all soil types. At $25^{\circ} \mathrm{C}$, second stage juveniles were found in all soil types but were more numerous in Coto (fig. 3B) and Fraternidad soils. Sausage stage nematodes were found occasionally in roots of $\mathrm{cv}$ Contender grown in Coto and Fraternidad soils. A few immature females were found in all soil types. Mature females were found more frequently in Coto and Fraternidad soils.

No mature females were found at $15^{\circ} \mathrm{C}$ in any of the soil types, but at $20^{\circ} \mathrm{C}$, egg masses containing many eggs were found in all soil types. In the Coto and San Antón soils, eggs had completed only the first stages of embryonic development whereas in Fraternidad soil juveniles had developed. At $25^{\circ} \mathrm{C}$, there were many females with large egg masses containing numerous eggs. Many of them had well developed juveniles, and recently hatched 2 nd stage juveniles toward vegetative tissues (fig. 3B). Fassuliotis et al. (6), studying susceptible snap bean cultivars, found that changes in soil temperature from 16 to $21^{\circ} \mathrm{C}$ or $28^{\circ} \mathrm{C}$ affected female development and increased egg production.

The number of individuals per gall varied from 1 to 9 . More nematodes per gall were observed in Fraternidad soil at $15^{\circ} \mathrm{C}$ in both eultivars, and in ev Contender grown in Coto and Fraternidad soils at 20 and $25^{\circ} \mathrm{C}$.

The number of giant cells was high in all treatments irrespective of the stage of nematode development. Giant cells varied in shape from round to ovoid or rectangular, depending on the invaded tissue. A tendency to the formation of long cells was observed when invaded tissues were associated to or near the vascular bundle (fig. 1A), whereas the giant cells were round in the cortex (fig. 2B). Román (12) working with 

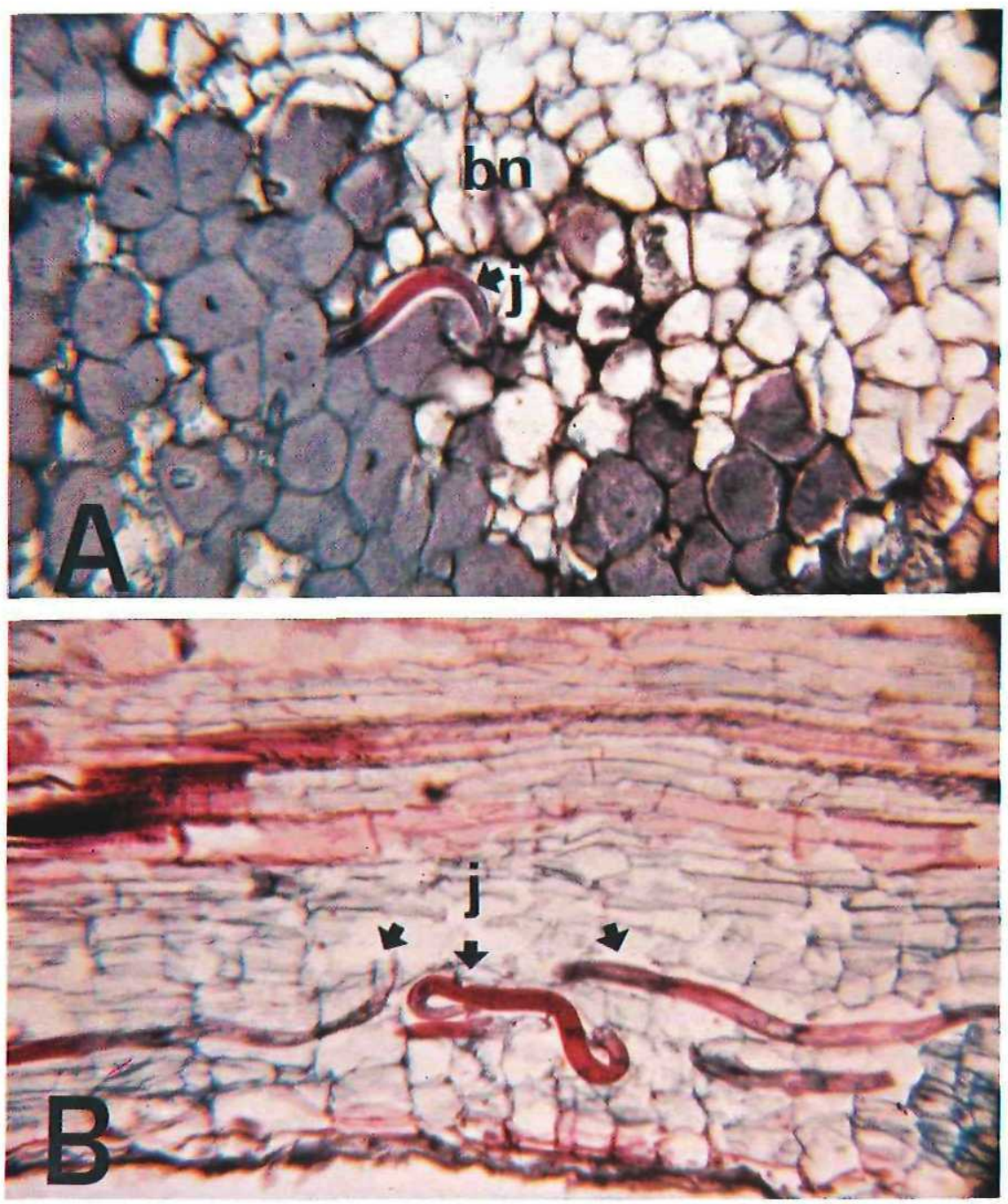

FIG. 3.-Histopathology of roots of snap bean cvs Conquest and Contender at $25^{\circ} \mathrm{C}$, 45 days after inoculation, with $M$. incognita. A) Transverse section of a portion of a bacterial nodule (bn), cv Conquest, exhibiting 2nd stage juvenile (j). B) Longitudinal section, cv Contender, exhibiting 2nd stage juveniles (j) migrating along cortical tissue. 
sugarcane roots, observed that giant cells were long in vascular system tissues. Toro (15) found similar results in several other crops. At $25^{\circ} \mathrm{C}$, giant cells appeared empty with little or no cytoplasm. Cell disorganization was evident in root tips. Long cell proliferation was also observed around giant cells in cv Conquest (fig. 1B). Apparently the stage of development of the nematodes and the number of specimens within the galls affected the appearance and cytoplasmic content of giant cells. The greater the number of nematodes within a gall and the more advanced the nematode stage of development, the lower the cytoplasmic content in giant cells.

The number of nuclei per giant cell varied from 3 to 40 . Giant cells with excessive nuclei proliferation were abundant at $20^{\circ}$ but less numerous at $25^{\circ} \mathrm{C}$. Multinucleate giant cells were most frequent in cv Conquest. These differences may be due to cultivars genotype. Giant cells with large numbers of nuclei were generally long or rectangular, suggesting a possible association with vaseular bundles.

In transverse sections, the space occupied by the nematodes and giant cells varied between $10-20 \%$ at $15^{\circ} \mathrm{C}$ and between $10-50 \%$ at $20^{\circ} \mathrm{C}$ and $25^{\circ} \mathrm{C}$ in relation to the total space of the section. No distinctive differences were observed at $15^{\circ} \mathrm{C}$, but giant cells in cv Contender were larger at 20 and $25^{\circ} \mathrm{C}$ (fig. $2 \mathrm{C}, \mathrm{D}$ ).

Mechanieal injury due to migration of juveniles was not observed in the root sections. It was observed that cells surrounding female bodies had mechanical injury due to nematode growth (fig. 2B).

The absence of necrosis in root sections confirmed the susceptibility of snap bean cultivars Contender and Conquest. Fassuliotis (5) noted hypersensitivity reactions in root tips of resistant cultivars and observed that migration of juveniles caused meristem and cortical parenchyma necrosis.

At the histological level, the effect of soil type on the nematode histopathology could not be ascertained since studied parameters resulted variable and somewhat erratic. However, a tendency to a better nematode development in Fraternidad soil was observed.

\section{RESUMEN}

La influencia de la temperatura $y$ el tipo de suelo sobre la histopatología del Meloidogyne incognitaen la habichuela tierna

El efecto a nivel histológico del nematodo nodulador, Meloidogyne in cognita (Kofoid and White) Chitwood se estudió en dos eultivares de habichuelas tiernas (Phaseolus vulgaris L.) sembradas en 3 tipos de suelos y mantenidas a 3 temperaturas. Las plantas de las cultivares Contender $y$ Conquest se sembraron en tres grupos de tiestos. En cada grupo se usó uno de los siguientes tipos de suelo; Coto franco-arcilloso, Fraternidad areillolimose y San Antón franco-limoso. Las plántulas se inocularon con 10,000 
huevos y segundos estadios juveniles de $M$. incognita y se colocaron en cámaras de crecimiento a 15,20 y $25^{\circ} \mathrm{C}$. Estudios histológicos de las raíces de las plantas, 45 días después de la inoculación, revelaron la formación de células gigantes con citoplasma multinucleado, de paredes gruesas, $y$ rodeadas generalmente, por una proliferación de células muy pequeñas. Se observó ruptura de paredes celulares, deformación de los haces vasculares y daño mecánico a las células adyacentes al cuerpo de la hembra del nemátodo. Se observaron nematodos invadiendo nódulos bacterianos, pero no así la formación de células gigantes dentro de éstos. Aumentos en la temperatura generalmente ocasionaron disminución en el contenido citoplásmico de las células gigantes. La cantidad de nematodos dentro de las raíces y la etapa de su desarrollo aumentó proporcionalmente con los aumentos en temperatura. Se observó una tendencia a la formación de células gigantes de forma ovalada o rectangular en la zonas cercanas a los haces vasculares y redondeadas en la corteza. Las células gigantes con mayor cantidad de núcleos predominaron a $20^{\circ} \mathrm{C}$, mientras que a $25^{\circ} \mathrm{C}$ disminuyeron. El tamaño de las células gigantes aumentó a $20^{\circ}$ y $25^{\circ} \mathrm{C}$, especialmente en la cv Contender. No se observó necrosis ni daño mecánico que se pueda atribuir a la migración de etapas juveniles. Se observó una tendencia a un mejor desarrollo del nematodo en el suelo Fraternidad.

\section{LITERATURE CITED}

1. Acosta, N. and J. A. Negrón, 1982. Susceptibility of six soybean cultivars to Meloidogyne incognita race 4, Nematropica 12 (2): 181-87.

2. and $J$. A. Negrón, 1982. Susceptibility of various tomato lines to a population of Meloidogyne incognita, Nematropica 12 (2): $173-80$.

3. Anónimo, 1984. Ingreso Bruto Agrícola de Puerto Rico, 1982/83-1983/84, Oficina de Estadísticas Agrícolas. Departamento de Agricultura de Puerto Rico. Santurce, P. R.

4. Dropkin, V. H. and P. E. Nelson, 1960. 'The histopathology of root-knot nematode infection in soybeans. Phytopathology 50 (6): 442-47.

5. Fassuliotis, G., 1982. Plant resistance to root-knot nematodes, $I n$ : Nematology in the Southern Cooperative Series, Bull, 276.

6. - - J. R. Deakin and J, C. Hoffman, 1970. Root-knot nematode resistance in shap heans. Breeding and nature of resistance, J. Am. Hort. Sci, 95 (5): 640-45.

7. Hussey, R. S. and K. R. Barker, 1974. Effects of nematodes with different feeding habits on nodulation of legumes, J. Nematol, 6 (4): 143 (Abstr.)

8. Johansen, D. A., 1940. Plant Microtechnique, McGraw Hill Book Co., Ine., N. Y.

9. Le Clerg, E. L., 1964. Crop losses due to plant diseases in the USA, Phytopathology 54: 1309-313.

10. Martínez, Miguel A., 1984. Estudio del efecto de las cuatro ruzas del nemátodo nodulador (Meloidogyne incognita) sobre cultivares de habichuela, Tesis M.S., Departamento de Protección de Cultivos, Univ. de Puerto Rico, Recinto de Mayagizez.

11. Negrón, J. A, 1980. Interacción de Meloidogyne incognita y Fusarium oxysponum $\mathrm{f}$, sp. coffene en Coffea arabica L., Tesis M.S., Departmento de Protección de Cultivos, Univ. de Puerto Rico, Recinto de Mayagiez.

12. Román, J., 1961. Pathogenicity of five isolates of root-knot nematodes Meloidogyne spp. to sugarcane roots, J. Agric. Univ. P. R. 45 (2): $55-84$.

13. - - 1978. Fitonematología Tropical, Esta. Exp. Agrie., Univ. P. R., Rio Piedras, P. R. 
14. Sasser, J. N., A. L. Taylor and A. L. Nelson, 1980. Ecological factors influencing survival and pathogenicity of Meloidogyne species, J. Nematol. 12 (4): 237 (Abstr.).

15. Toro, J. A., 1978. Relaciones hospedero-parásito y la variabilidad de catorce poblaciones de nemátodo nodulador, Meloidogyne spp. en Puerto Rico, Tesis M.S., Departamento de Protección de Cultivos, Univ. de Puerto Rico, Reeinto de Mayagỉez.

16. Vicente, N., 1983. Efecto de algunos factores ecológicos en la relación huésped-parásito y la variabilidad de Meloidogyne incognita en dos variedades de habichuela tiema (Phaseolus vulgaris L.), Tesis M.S., Departamento de Protección de Cultivos, Univ. de Puerto Rico, Recinto de Mayaguiez.

17. Wallace, H. R., 1973. Nematote Ecology and Plant Disease, Edward Arnold, London.

18. Wyatt, J. E., G. Fassuliotis and A. W. Johnson, 1980. Efficacy of resistance to rootknot nematode in snap beans, J. Am. Soc. Hort. Sci. 105: 923-26. 
